\title{
The role of values for niche expansion: the case of solar photovoltaics on large buildings in Sweden
}

Martin Warneryd ${ }^{1,2,3^{*}}$ (i) and Kersti Karltorp ${ }^{1,4}$

\begin{abstract}
Background: Solar photovoltaic (PV) plants can contribute to the transformation of the electricity system in Sweden not only by adding capacity, but also by forming new decentralized ownership structures and involving new actors. This article focuses on solar PV plants on larger buildings, which represent a significant share of the installed capacity (although the total capacity is still very low in Sweden) and which have a good future potential. We are interested in the reasons owners of large buildings have for investing in solar PV plants, despite the fact that they face a complex regulatory situation. The aim of this paper is, therefore, to identify added values from solar PV plants for large buildings and to see how these values contribute to the ongoing expansion of the solar PV niche in Sweden. We use sustainability transitions as the theoretical point of departure and focus particularly on the role of values in an expanding niche. Data was collected via 15 semi-structured interviews, mainly with large building owners. It provides an interesting empirical case of the pioneers within the actor group of large building owners who potentially can play an important role in the expansion of solar PV technology in Sweden.

Theoretically, the article contributes to the sustainable transition research field by demonstrating how values are developed and affect the niche-regime interplay.

Results: The findings demonstrate that owning a solar PV plant adds values such as sustainability, fair cost, and induced innovativeness. These values have an effect on niche expansion by contributing for example to the development of a social network, new role development, positive niche narrative, and niche empowerment.

Conclusions: We conclude that the broad set of values added by solar PV plants on large buildings increases the desire and enhances the positive experience to take on a new role development. Furthermore, we conclude that added values contribute to developing a social identity which is important when expanding the social network around the niche. Finally, we conclude that added values shape the positive niche narrative among niche advocates and give direction for policy development related to the niche.
\end{abstract}

Keywords: Solar photovoltaics, Sustainability transition, Values, Niche expansion, Large buildings

\section{Background}

Increased deployment of renewable energy technologies is transforming the global energy systems with solar photovoltaic (PV) standing out as the most rapidly diffusing technology [1]. In Sweden, solar PV deployments have increased steadily over the last decade. Despite this, the share of deployment is still low, only accounting for about $0.2 \%$ of the total electricity production [2]. The

\footnotetext{
* Correspondence: martin.warneryd@ri.se

${ }^{1}$ RISE, Research Institutes of Sweden, Box 857, SE-501 15 Borås, Sweden

2Dalarna University, SE-791 88 Falun, Sweden

Full list of author information is available at the end of the article
}

Swedish government aims to increase this and has adopted a vision of at least a five but possibly a $10 \%$ share of solar PV by 2040 [3]. Although the envisioned percentage is still only a tenth of the total production, it will potentially affect the energy system more than by just substituting one technology for another, due to its decentralized feature.

Solar PV plants are often installed directly on electricity consumers' homes or other owned properties. This means that not only the technology for electricity generation is changed but also the role and responsibilities of the electricity consumers themselves. Raven et al. [4] 
compare different low-carbon technologies and find that solar PV is by far the most unlike current production technologies and will need the largest changes to the existing electricity infrastructure to be able to be integrated satisfactorily. This means that, as the number of solar PV installations increases, traditional electricity companies and grid operators are increasingly affected and need to handle the new decentralized production and ownership structure. Büscher and Sumpf [5] state that this development will increase the apprehension of risks felt by different actors in the electricity system. As consumers become producers, their ability to actively influence and take action in the new decentralized structure will be vital [5]. Laws and regulations as well as practices and behavior are still mainly adapted to the current centralized infrastructure. A further expansion of solar PV will most likely require amendments to these regulations. Some policy measures targeting solar PV deployment have already been implemented in Sweden, such as a tax exemption for self-production, a feed-inpremium for excess production, and an investment subsidy [2]. Further, awareness of the possible effects of a decentralized electricity system is seen in some authority reports and proposals. One example of this is the newly adapted EU directive on the promotion of using energy from renewable sources which states that renewable selfconsumers and communities should be entitled to generate, consume, store, and sell renewable energy without disproportionate procedures and charges [6]. A Swedish example is found in a recent investigation which focused on small-scale users in the electricity system [7]. This report acknowledges that the growth of solar PV will probably contribute to decentralizing the electricity system and challenge the existing policy structure (ibid). However, the task of changing policy to include a decentralized production infrastructure is complicated by the heterogeneity of potential small-scale producers. At the same time as they become solar PV electricity producers, these actors will have different effects on the electricity system, given their background and presence in the market.

Larger residential and commercial buildings have great potential for solar PV deployment. Looking at the number of medium-sized plants which are often installed on the building envelope, they provide a significant share of around two thirds of the total installed capacity in Sweden [2]. Owners of these buildings are a heterogeneous group and consist, for example, of property owners, housing companies, and cooperative housing associations. Due to the variety, actors in this group face different situations in terms of regulation. For example, a feed-in-premium is applicable only with small main fuse sizes $(<100 \mathrm{~A})$ meaning that larger buildings with larger main fuse sizes do not obtain this premium [8]. Moreover, tax exemption for production for their own consumption is not possible when distributing electricity over several buildings, even though the buildings are within the same organization [9]. Despite this, several different actors invest in solar PV plants, which lead to the question on what reasons motivate them.

In the field of sustainability transition research, the dominant technological and social system of a certain field in society is termed a sociotechnical regime [10]. What is important from this perspective is the inclusion of a technological as well as a social system, and how the two are interconnected and also interdependent of one other. In current electricity systems, this would be the centralized large-scale production and transmission infrastructure and associated actors as well as institutions. The word regime implies that this system is very resistant to changes. Solar PV and other decentralized generation technologies are seen as niche technologies which evolve in a space protected from regime logics [11]. As the niche expands, more interaction with the regime will take place. In addition, the inclusion of other sociotechnical regimes, such as the housing sector in the electricity system, affects the expanding niche. In some cases, the regime can be destabilized and replaced by the niche [12]. A niche does not only imply new technologies and practices but also a specific rule structure which includes the values, beliefs, and norms of the niche actors [12]. The expanding niche deals mostly with changing the existing rule structures established by the regime [13].

In previous studies on solar PV expansion in Sweden, Palm [14] identifies specific diffusion parameters by looking at geographical differences in the concentration of deployed solar PV plants. Palm describes how a strong proactive actor, often a utility, influences the number of deployments in the area near to the actor's business [14]. This indicates the importance of a proactive regime actor in the expanding niche. Other studies $[15,16]$ show that user-based ownership of solar PV plants has the potential to transform the energy system. In particular, civil participation stemming from new organizations and grassroot initiatives affects the diffusion rate of renewable energy technologies (e.g., [17-20]). When these types of organizations participate, several values can be experienced leading to greater acceptance of the technology and faster diffusion [20]. Solar PV specifically might increase engagement in the community when added to community energy systems and seems to be a means to an end for increasing social coherence [21, 22].

Sommerfeldt and Muyingo [23] investigated three cooperative housing associations with solar PV plants in Sweden and concluded that the original motivation of lowering operating costs was not satisfactorily fulfilled. Despite this, the cooperatives viewed their solar PV plants as a success due to the social and environmental benefits which were originally less important, but gained importance as the process advanced [23]. This study 
indicates that these actors alter their views when experiencing additional values as they incorporate solar PV in their organizations. Insights from these previous studies show that there are several reasons for investing in solar PV plants and that these can change over time. Although connections between values and solar PV seem to exist, there are no studies on how these values relate to the expansion of the niche and affect the nicheregime interplay. Given the potential for solar PV on large buildings in Sweden, it is interesting to focus particularly on this group of actors and the reasons they have for entering the solar PV niche.

To guide this research, two questions have been formulated: (i) what added values do actors with large buildings associate with their solar PV plants and (ii) how do these values contribute to the ongoing expansion of the solar PV niche in Sweden? Data was collected through 15 semi-structured interviews mainly with owners of large building solar PV plants. It provides an interesting empirical case of the pioneers within the actor group of large building owners who potentially can play an important role for the expansion of solar PV technology in Sweden. This group can be seen as a case of community energy where the influences of solar PV technology are focused. The article also contributes to the theory of the sustainable transition research field by demonstrating how values are developed and affect the niche-regime interplay.

The article is organized as follows: First, a description of theoretical departure points continues the Section 1 in Subsection 1.1. Then Section 2 presents the method, including data collection and data analysis. Section 3 presents the findings followed by a discussion in Section 4. Finally, conclusions are made in Section 5.

\section{Theoretical departure points}

The theoretical departure points draw on insights from the sustainability transition research field. Interplay between the decentralized solar PV niche and the centralized regime will be the departure point in the analysis. Emphasis will lie on how values shape this expansion and strengthen the niche.

An important distinction to be made is between value and values. In business research, value is something that individuals can experience from consuming something (or producing something for their own purposes). Values, on the other hand, shape how the individual perceives the value of the consumed goods [24]. Thus, values affect the desirability and preferability of specific goods. Of course, values are not only related to consumable goods, instead, as pioneering sociologist Durkheim pointed out; values enable individuals to feel that they are part of something bigger, for example, they affect people's choice of what is considered good and bad and help define the collective identity of a social group [25]. Therefore, values affect attitudes and motivations among individuals and organizations. The two terms, values and value are related and Ledden et al. [26] describe the relationship between value and values as "value is related to, but distinct from, the concept of values". The fact that there is a relationship between value and values is a fundamental departure point for this study.

\section{Niches, regimes, and sustainability transitions}

Research into sustainability transitions strives to understand the mechanisms behind large-scale societal transformation toward increased sustainability [27]. When describing sustainability transitions, they are often referred to as interactions between societal systems at different levels and outlined using the multi-level perspective (MLP) framework $[10,12]$. The sociotechnical regime, which is a resisting societal system of practices and rules formed by multiple actors such as industry, policy, culture, and science, represents the meso level in this framework; at the micro level, niches which bring new innovative technologies are found; and, at the macro level, landscapes exist which represent overarching external factors. The regimes are characterized by resilience, and lock-in to existing technological, social, and cultural systems [28]. Niches provide a protected space for technologies to be developed without being outcompeted from the mainstream selection environment of the regime [12]. This protection is sometimes formally established by legal frameworks, but can also include informal institutions such as discourses lobbied from advocacy coalitions, R\&D funds, and certain target customers willing to pay higher prices for premiums such as environmentally sound products [11, 29].

Both regimes and niches share common rules which coordinate action within the sociotechnical communities, although niches are characterized by initial instability and low performance [12]. Stemming from institutional theory, these rules are of different natures; regulative, normative, and cognitive. Examples of regulative rules are formal laws, standards, and regulations; examples of normative rules are role-relationship, values, and behavioral norms; and cognitive rules can be several such as belief systems, guiding principles, and innovation agendas. These rules commonly affect niches and regimes in what sociologists call embedded rule structures. This means that the rules exist implicitly and become explicit when influencing practices and decisions of actors within the sociotechnical systems [12]. Thus, values play an important role in influencing structural changes in sociotechnical systems.

Regimes are characterized by constraining structures which need destabilization to be transformed. Niches are characterized by enabling structures contributing to the development and diffusion of innovative technologies 
and practices [12]. The landscape can affect the niche and regime, particularly in the form of external shocks such as a financial crisis, or trends such as increased divestment in the fossil sector. When they occur, they can provide a "window of opportunity" for the niche to challenge and eventually destabilize the regime and become part of the new dominant regime [12]. What often happens as a result of a window of opportunity are changes in what is considered mainstream beliefs and values by policy actors, paving the way for innovative niches [30].

In a niche's initial phase, there is relatively low interaction with the regime [31]. If the niche grows stronger and expands with larger markets and more niche actors, there will be more interaction with the regime(s). This phase is often referred to as niche expansion [31] and is characterized by complexity, regime resistance, regimeregime interplay, and influence from landscape factors $[28,31,32]$. Here, the struggle is intensified between the niche and one or several regimes over which rules should dominate [28].

\section{The expanding niche and transformed values}

Several processes occur as the niche expands. Niche expansion affects actors' roles both in regimes and niches. As the niche expands, roles change and these changes can be seen as indicative changes in shared values, norms, and beliefs [13]. It means that the role changes between regime and niche actors are not just passively accepted, but rather actively undertaken, since these role-relationships are part of the common rule structure $[12,13]$.

Niches are legitimized and powered by the growth of a strong social network of niche advocates telling a positive niche narrative $[4,33]$. These social networks become stronger with a larger number of actors, but also important with the inclusion of specific influential actors, such as regime actors [34]. For example, both Markard et al. [30] and Wittmayer et al. [13] describe how advocacy coalitions changed shared values, norms, and beliefs as renewable energy became the new mainstream.

As the social network of niche advocates grows, other strong actors from different regimes could influence the expanding niche [31]. For example, Sutherland et al. [35] look at the inclusion of agriculture in the electricity regime, via farmers starting to produce electricity or renewable raw material for combined heat and power generators. They see that inclusion of multiple regimes can provide stability to the expanding niche and also show directions for development in both the niche and other regimes [35]. These directions are linked with the included actors' embedded rule structures which, in turn, affect niche expansion [35, 36].

For the niche to be able to gain stability and power to challenge the regime(s), it needs empowerment [37]. Smith and Raven [11] distinguish two empowerment strategies.
The first is the adaption to the regime selection environment and, thus, gain strength in a traditional environment to compete with a similar logic as the regime, called the "fit and conform" strategy. An example is how energy cooperatives in the Netherlands joined forces to apply for a permit collectively, since mainstream regulations were aimed at large energy companies, and compliance was extremely difficult without the larger entity which was created through the collective [38]. The second strategy can be to provide a different (marketed by niche advocates as "better") alternative to the regime rules, creating pressure on the selection environment to adapt to the niche rules instead of the regime, called the "stretch and transform" strategy. One can also view the different strategies as different transition pathways; however, a niche does not always follow the same pathway through its development. A stretch and transform pathway can be switched to a fit and conform pathway after a specific event such as a governmental induced cut in subsidies affecting the niche technology [34].

To summarize, values are part of the common shared rules of the sociotechnical system. Values can affect the expanding niche through the (i) role development, (ii) social network development, (iii) the inclusion of other regimes in the niche, and (iv) empowerment strategy.

\section{Methods}

The research process of the study began by investigating relevant background literature and theories on sociotechnical change and values. These were then used to create an interview guide and a theoretical framework for the data analysis.

\section{Data collection}

This study is based on primary sources, in the form of interviews. The major group of respondents represented different large building actors. All actors had experience of solar PV plants; either from their own building(s) or through utilizing available space on another actor's building. In addition, based on the theory describing the expanding niche highlighting inclusion of regime actors, some utility companies were interviewed to gain their perspectives on the expanding niche. All respondents were chosen based on their proactivity, i.e., their respective organizations have been pioneers in the market. In particular, the utilities have a record of being proactive in the development of the solar PV market by offering solar PV services early on.

In total, 15 semi-structured interviews were conducted for this study: 13 with owners of large buildings who had installed solar PV and two utility companies (Table 1). Guiding interview questions, found in Additional file 1, were developed beforehand and used during the interviews. The chosen interview persons represented their respective organization as a whole, and no questions were intended to 
Table 1 Overview of interviews for the study

\begin{tabular}{|c|c|c|c|c|}
\hline $\begin{array}{l}\text { Type of organization } \\
\text { interviewed }\end{array}$ & PV capacity & $\begin{array}{l}\text { Year of (first) } \\
\text { installation }\end{array}$ & Short description & $\begin{array}{l}\text { Interview } \\
\text { number }\end{array}$ \\
\hline $\begin{array}{l}\text { Cooperative housing } \\
\text { association (CHA) } 1\end{array}$ & Ca $60 \mathrm{~kW}$ & 2015 & \multirow{4}{*}{$\begin{array}{l}\text { Share owned association where all members live in apartments } \\
\text { in a common building. Capital investment matching the market } \\
\text { value of their apartment is mandatory. }\end{array}$} & 1 \\
\hline $\mathrm{CHA} 2$ & Ca 60 kW & 2016 & & 2 \\
\hline CHA 3 & $30 \mathrm{~kW}$ & 2015 & & 3 \\
\hline CHA 4 & $33 \mathrm{~kW}$ & 2014 & & 4 \\
\hline $\begin{array}{l}\text { Rental housing cooperative } \\
\text { (RHC) }\end{array}$ & $100 \mathrm{~kW}$ & 2017 & $\begin{array}{l}\text { Cooperatively organized tenants who are responsible for common } \\
\text { areas of their apartment building. Can own common facilities or } \\
\text { the entire building. }\end{array}$ & 5 \\
\hline Share cooperative (SC) 1 & $\begin{array}{l}598 \mathrm{~kW} \text { where } \\
74 \mathrm{~kW} \text { is roof } \\
\text { mounted }\end{array}$ & 2009 & \multirow[t]{2}{*}{$\begin{array}{l}\text { Consists of share owners of one or several common solar PV plants. } \\
\text { Every share has a fixed price. }\end{array}$} & 6 \\
\hline SC 2 & $25 \mathrm{~kW}$ & 2015 & & 7 \\
\hline Village community (VC) & N/A & N/A & $\begin{array}{l}\text { Community of individual houses, sharing common property and } \\
\text { are responsible for collective services }\end{array}$ & 8 \\
\hline Cooperative farm (CF) & $32 \mathrm{~kW}$ & 2017 & Farm owned by ten families in a cooperative organization & 9 \\
\hline Property company (PC) 1 & N/A & 2013 & \multirow{3}{*}{$\begin{array}{l}\text { Development and maintenance of commercial and residential } \\
\text { buildings for tenants and sometimes for sale (to a CHA). }\end{array}$} & 10 \\
\hline PC 2 & N/A & 2013 & & 11 \\
\hline PC 3 & N/A & N/A & & 12 \\
\hline Housing company (HC) & 78 kW & 2016 & $\begin{array}{l}\text { Development and maintenance of apartment buildings for private } \\
\text { households. }\end{array}$ & 13 \\
\hline Electricity company (Utility) 1 & N/A & N/A & \multirow{2}{*}{$\begin{array}{l}\text { Electricity trade companies which offer several PV related products } \\
\text { such as complete hardware systems and tariffs for grid-fed electricity }\end{array}$} & 14 \\
\hline Utility 2 & N/A & N/A & & 15 \\
\hline
\end{tabular}

find the person's individual preferences. The number of actors from similar organizations was based on availability, since some had very few representatives. In organizations where many actors existed, sufficient data from iterations in interview responses guided the number of included actors. The largest groups of similar organizations are cooperative housing associations (CHAs) and property companies (PCs) along with the utilities. These organizations have also the most representatives in the study. The rental housing cooperative (RHC) and the cooperative farm (CF) are unusual organizations (only these two to our knowledge have deployed solar PV) and can provide examples for future developments in the area. Also, the share cooperatives (SCs) are rare with around five active in Sweden in total. Many village communities (VCs) can be found; however, the included VCs emphasize their work with solar $\mathrm{PV}$ as a main activity within the community. Recently, housing companies (HCs) in Sweden have begun installing solar PV; however, the included $\mathrm{HC}$ was an early-adopter and has gained long experience, working with solar PV in its property stock. The interviews were all conducted in Swedish, mainly during the period December 2016 to April 2017, with some additional interviews in February 2018.

\section{Data analysis}

The interviews were transcribed and thereafter coded (using MaxQDA) manually by identifying themes related to values. Sometimes, several themes were combined in one overall theme since they were related. The sets of values were then analyzed according to the theoretical framework to see how they linked to niche expansion. Table 2 provides examples of how the analysis was done, showing text segments which have been coded to different values and how this is considered to link to niche expansion.

\section{Results}

In this section, the empirical findings are presented and analyzed according to the theoretical departure points.

\section{Added values from the expanding solar PV niche}

Several added values were experienced by the actors in the study: sustainability, fair cost, active engagement, induced innovativeness, increased knowledge of the energy system, and a positive atmosphere.

\section{Sustainability}

Several interviewees consider that installing solar PV is a concrete action to contribute to sustainable development in society (interviews 1,4-13). This was also a value which was present in many of the actors' core values. By utilizing the available solar irradiation on the building, different organizations contribute to improved resource efficiency and locally produced and used electricity 
Table 2 Examples of how the analysis was performed from the transcribed interview data

\begin{tabular}{lll}
\hline Examples of transcribed interview (translated into English by article authors) & Value & Link to niche expansion \\
\hline "...we should do as much as we can to contribute to sustainable development. & Sustainability & Developing identity as sustainably proactive \\
$\begin{array}{l}\text { We alone cannot do much, but at least this is something that we can do" } \\
\text { "...thinking about a DC network between three buildings with intelligent energy } \\
\text { hubs. It's stimulating being involved in development projects, not just being a } \\
\text { real estate agent." }\end{array}$ & $\begin{array}{l}\text { Induced } \\
\text { innovativeness }\end{array}$ & $\begin{array}{l}\text { Role development and inclusion of other } \\
\text { regime actors in the niche }\end{array}$ \\
$\begin{array}{l}\text { "An important aspect is that with this installation we can now show a concrete } \\
\text { example to others, that this is economically feasible even for a small actor such } \\
\text { as ourselves" }\end{array}$ & Fair cost & $\begin{array}{l}\text { Development of niche narrative and } \\
\text { social network development }\end{array}$ \\
\hline
\end{tabular}

(interviews 1, 5). In addition, the marketing aspect is important, and the value of sustainability makes it possible to market the organization positively. The RHC and one of the PCs use the solar PV installation to market their respective organizations as sustainable (interviews 5,6 )

\section{Fair cost}

A common response from the different interviewees was that owning a solar PV plant provided a lower cost for electricity, which was something the studied actors strived to achieve. Not only the cost was reported to be lower, but also fairer according to the interviewees. Two examples are used to demonstrate what is included in this value. First, the RHC discussed how rental income could be efficiently invested in its own building without providing margins for third parties. Since a PV plant utilizes available resources from solar irradiation on the building, it contributes to the reduction of margins for the utility company (interview 5). As well as lowering the overall cost for electricity production, the investment also decreases volatility in electricity prices and provides a more stable cost planning: "An important difference with the [solar] PV plant is that it lessens the dependency on bought kWh's, and therefore also volatility in electricity prices which provides a more stable electricity cost. Moreover, the total cost is less than before in the long term." (interview 5).

The SCs and the VC in the study were also motivated by the possibility of increasing solar PV in the electricity system and providing opportunities for owning a solar PV plant without available space for installation (interviews 6-8). The Electricity Act, however, states that all production other than on a user's own property and inside the grid connection point is termed commercial production and should be taxed accordingly. This means that SC members must pay commercial taxes, such as utilities, for their production even though each member only owns a small part which is less than the member's own consumption. Cost savings are therefore much less in this group. SCs feel that this is unfair to people who do not have sufficient space to install a solar PV plant. They criticize current legislation since they believe that cost savings should be fair for all who invest in solar PV for their own consumption (interview 6-7).
Fair cost represents therefore experiences of lower costs, more control over cost, and less dependency on utility tariffs.

\section{Active engagement}

All interviewees consider that the process of installing a solar PV plant has increased their respective organization's engagement in their local electricity system. This engagement was originally connected with the initiators but has, during the process of installation, also spread to further members in the actor's organization: "the plant has actually created a greater engagement in the housing cooperative by its members" (interview 1).

Engagement related with solar PV plants is expressed in several ways. In one of the PCs, engaged employees have experimented with different solutions to optimize the efficiency of the solar PV plant and have tested different business models (interview 10). In the RHC, a broad learning process with seminars and invited experts took place during the installation phase, which encouraged tenants to gain more knowledge about their own electricity system (interview 5). In addition, to make the installation process more transparent and minimize uncertainties, a co-working group was created which followed the project managers and lead to increased trust in the technology and in the cost calculations among members: "an important part of the process was when some members voluntarily took part in the process by learning about the technology and the cost calculations to understand what the prospect looked like. These members could later verify that the calculations were reasonable, and in this way create greater trust for the project among the rest of the members." (interview 5).

Solar PV plants can also be used to engage external interest for the actor, e.g., by increasing employer attractiveness or engaging students in $\mathrm{PV}$ plant projects (interview 10). In the VC, there is no actual common solar PV plant as yet, only a number of individual plants among the members. However, after initiating discussions around cooperatively owning a solar PV plant in the $\mathrm{VC}$, members' engagement has increased. As a result, different interests, e.g., technology, democratic electricity production, lower cost, and self-sufficiency, have 
been brought together. So far, this has led to the organization of information meetings and community support to members wishing to install their own PV plants (interview 8). External engagement is also seen via interest from similar actors wishing to install their own plants, e.g., one CHA provides study visits to other CHAs (interview 4).

There were also examples when engagement did not reach everyone in the actor's organization. For example, in one of the CHA, several members were satisfied with the installation, but it did not increase their interest in the technology or involvement further (interview 2). In the $\mathrm{HC}$, some engagement existed initially, which also led to a first solar PV plant installation, but it took a long time to convince the management to prioritize the technology. Today, every new construction project is evaluated for a solar PV plant (interview 13).

\section{Increased knowledge of the energy system}

The interviewees experienced that it was necessary to increase their knowledge about the energy system to be able to install the solar PV plants: "We had to learn all the new concepts and terms ... ... we felt that it was necessary to do this" (interview 9). The main knowledge gaps which needed to be filled were PV technology and legislative frameworks for micro-producers. The process of installing a solar PV plant was discussed within the different actors' organizations. What was learnt by the project managers was spread to the larger group through the presentation of facts and figures and through discussions. In the CF, several members were at first skeptical to a solar PV plant. After the project manager had sent out information movies and a member had spoken to another solar PV plant owner, their skepticism was reduced, although some people still held their initial view. The resistance was also due to low willingness to learn about the new solar PV plant (interview 9).

The examples show that information and learning have been natural parts of the process required for the actors to install solar PV plants. This means that knowledge about energy systems was gained, sometimes by a few members, and sometimes by the majority of the members.

\section{Induced innovativeness}

Electricity generation has, historically, not been part of the studied actors' regular activities, except for the share cooperatives which were founded specifically for solar PV plants. Since commencing the processes to become an electricity producer, an experimental curiosity has evolved. For some actors in the study, mainly the PCs but also the RHC and $\mathrm{HC}$, it is indeed a core value to be innovative, and solar PV engagement has increased this practice. One PC expresses the following: “...thinking about a DC network between three buildings with intelligent energy hubs... It's stimulating being involved in development projects, not just being a real estate agent" (interview 10). Now, they can also be innovative in activities which relate to their own electricity production and this inspires further system development.

Several actors target buildings that generate more electricity than they consume (called plus buildings) and experiment with related technologies such as batteries, smart applications, electric vehicles, and microgrids (interviews 5, 10-11). To quote one of the PCs: "In our profile project we're thinking about including electric vehicles and using old bus batteries to be integrated in the energy system" (interview 11). In this way, the actor continues to innovate in the electricity system gaining knowledge around a decentralized production infrastructure.

In addition, other actors show curiosity in developing the electricity systems further, both from a technical and organizational perspective. One of the SCs in the study discussed and tested solutions and business models with the goal of increasing profitability and attracting more members into the cooperative (interview 6).

\section{Positive atmosphere}

Being part of electricity production via solar PV creates a positive feeling among members. The installations are usually seen as something good which enhances the positive atmosphere in the actor's organization: "The months we've had production data, I've included this in the monthly letter to members ... ... this was received with great cheers among the members" (interview 1). There is a sense of pride among the members and employees which arises for several reasons: contribution to environmental sustainability, a good feeling from producing their own electricity, less reliance on an external electricity supply, a sense of accomplishment (e.g., we achieved this together), improved finances, sometimes esthetic improvements, and an environmental profile (all interviews). Moreover, the installations were seldom in conflict with the views and interests of members of the respective organization; instead, they have conformed to core values and visions, even though they are not part of core activities.

\section{Summary of added values}

Table 3 summarizes the added values and explanations.

\section{Role development through added values}

The role development is not a passive change of roles, such as suddenly becoming an electricity producer after installing a PV plant. Instead, as described in the theoretical framework, the role development comes from the involved actors' changes in norms, values, and beliefs. The results show that added values have an effect on 
Table 3 Summary added values from solar PV ownership

\begin{tabular}{|c|c|c|}
\hline Value & Description & Effects on actor \\
\hline Sustainability & $\begin{array}{l}\text { Solar PV increases environmental sustainability } \\
\text { by adding renewable electricity production. }\end{array}$ & $\begin{array}{l}\text { Fulfilling actors endeavor to act more sustainably in a } \\
\text { concrete way. Facilitates marketing of organization. }\end{array}$ \\
\hline Fair cost & $\begin{array}{l}\text { Solar PV reduces costs for electricity consumption } \\
\text { in most cases, which is viewed as fair since the } \\
\text { actors have invested in production infrastructure. }\end{array}$ & $\begin{array}{l}\text { Enhanced and more control of actors' economy, by less } \\
\text { dependency on utility bought electricity. }\end{array}$ \\
\hline Active engagement & $\begin{array}{l}\text { Installing and running a solar PV plant increases } \\
\text { engagement by members in respective organizations. }\end{array}$ & $\begin{array}{l}\text { Enhanced experienced social value via the increased } \\
\text { engagement from members. }\end{array}$ \\
\hline $\begin{array}{l}\text { Increased knowledge } \\
\text { of the energy system }\end{array}$ & $\begin{array}{l}\text { Owning and running a solar PV plant increases } \\
\text { knowledge of the energy system. }\end{array}$ & $\begin{array}{l}\text { Knowledge increases which is viewed as interesting and fun. } \\
\text { Prerequisite for more resource efficient behavior by consumers. }\end{array}$ \\
\hline Induced innovativeness & $\begin{array}{l}\text { Solar PV plants encourage experimentation with } \\
\text { other solutions. }\end{array}$ & $\begin{array}{l}\text { Actors increase activities related to their own electricity system } \\
\text { and become infrastructure developers by experimenting with } \\
\text { additional technology or business models. }\end{array}$ \\
\hline Positive atmosphere & $\begin{array}{l}\text { Solar PV plants enhance the positive atmosphere } \\
\text { in the organization by making members proud } \\
\text { and engaged in the organization. }\end{array}$ & $\begin{array}{l}\text { Overall the atmosphere in the organization is enhanced which } \\
\text { increases social value and generates greater attractiveness from } \\
\text { external actors. }\end{array}$ \\
\hline
\end{tabular}

changing these parameters. Specifically, the roles of electricity producer and electricity infrastructure developer are highlighted.

Fair cost provides further autonomy from the utility and strengthens the self-supportive role of the organizations. This implies that the value enhances the role of being an electricity producer, although this role differs in character from the utility role which is profit-driven. Increasing responsibilities which follow the shift from passive consumer to active producer are influenced by active engagement in, and increased knowledge of, the energy system that the organizations experience. The RHC clearly expresses this as desirable (interview 5). Here, the active role of electricity producer with increased responsibilities fits very well with the general values the RHC targets and is now enhanced by added values from solar PV. Other organizations express similar attitudes toward an increased self-supportive role enhanced by fair cost and active engagement (interviews 1-3). The PCs and the $\mathrm{HC}$ have a commercial interest in developing their activities. Fair cost and increased sustainability enhance their desire to be electricity producers with additional solar PV plants, since this reduces costs and markets them as sustainably proactive (interviews 10-13).

Induced innovativeness leads the organizations to become infrastructure developers in the new decentralized electricity system. Several CHAs aim to initiate common contracts with the utility and sometimes also connect further buildings or businesses within their building to their common contract (interviews 1-4). This extends their local electricity system further and actively consolidates their new role as infrastructure developers. The PCs and the RHC name opportunities to further develop their systems and integrate additional technologies such as storage, electric vehicles, and a microgrid (interviews 5-7). This means that they are actively pursuing the role of infrastructure developers.
To summarize, two new roles are actively being developed: electricity producer and electricity infrastructure developer. These roles differ in character from utility roles since they are pursued from different reasons and connected to the experienced values of sustainability, fair cost, active engagement, increased knowledge of the energy system, and induced innovativeness. Thus, these values shape the way these roles are being actively undertaken and are therefore connected with the specific role development in the decentralized niche. When this fits the organization logics, it is desirable to enhance and further develop these roles, strengthening the niche with more developed rule structures.

\section{Social network development in the expanding niche}

As outlined in the theoretical framework, the build-up of a social network is essential for the expanding niche.

A recurrent subject in the interviews, although from different angles, is sustainability. The previously described value sustainability relates to environmental sustainability. In addition, descriptions of pride and positive atmosphere, as well as increased engagement relate to sustainability from a social point of view. Increased cost control and less dependency on the utility company as well as induced innovativeness relate to economic sustainability. Hence, all three dimensions of sustainability are affected by added values from the solar PV plants. Several actors have adopted sustainability as a core value in their respective organizations (interviews 1, 5-8, 10$11,13)$. This facilitates a common identification among the organizations as sustainably proactive, and the values are utilized to advocate the benefits of the niche.

Positive experiences and pro-activism for sustainability also enhance the narrative to external actors, and the PV plants attract attention from several instances. Three of the CHAs have been interviewed in local and national newspapers (interviews 1, 2, 4). The RHC has attracted 
both researchers and politicians interested in the project (interview 5). In addition, the PCs are often invited to share experiences from their work with solar PV at different events and fairs. One SC is frequently contacted by interested people who plan to set up similar organizations (interview 6). One CHA hosts study visits from interested associations (interview 4), while the other CHAs are open to anyone who makes enquiries. In this way, the niche narrative is diffused among similar organizations. For the RHC, one of the most important purposes with the installation was to provide an example of sustainable and cost-efficient living for other similar apartment blocks (interview 5).

In summary, added values from the solar PV plants facilitate social network development through enhanced group identification as sustainably proactive and attract external interest as well as creating a desire to increase the social network through outreach to potential niche adopters.

\section{Inclusion of regime actors in the expanding niche}

As the solar PV niche expands, actors from both the current electricity system regime and other regimes, such as the housing sector, enter into the niche.

Utilities are affected by the rise of solar PV and have different strategies to cope with decentralized electricity production. Solar PV creates a range of new possibilities, e.g., energy services, and the interviewed utility companies experience a positive effect on customer relations (interviews 14, 15). One of the utility companies finds close relation with, e.g., CHAs interested in solar PV necessary since they need guidance in the complex regulations and installation procedures related with the technology (interview 14). This insight has also spread to other business areas: "the relation with the customer has improved a lot, now it is part of our general strategy, to work close with the customer and build long-term relationships" (interview 14). Here, it is clear that the utility adapts the niche technology and sees the value for itself in this development. Today, the necessities of decentralized energy, to have a close customer relation, has changed the regime actor's previous rule structures and fed in the niche rules as general practice. The second utility company was founded on solar PV development since they realized that solar PV enabled the values of equality and democracy through user-based ownership and reasonable costs. This provides an example of how the traditional regime actor can be challenged by niche actors which take on the previous utility role, but with more niche specific rationales. However, since they see the regulations with larger actors as too complex for their current capacity, they have so far not included this group in their offerings (interview 15). This shows that institutions are still partly in favor of centralized regime logics. It does not however hinder the second utility to advocate for niche technologies, and other actors in this study have been inspired by the utility company since they offer study visits, provide guidebooks, and consultancy for anyone interested in solar PV (interviews 6, 7).

The shifted focus to customer value has affected the utilities' business model. This is connected with developing a social identity, i.e., being sustainably proactive in the social network of the expanding niche. Hence, these utility companies have become niche advocates in the social network supporting decentralized electricity production and ownership.

The included PCs and HC already hold strong positions in the housing sector, which is a different sociotechnical regime than electricity production. After installing solar PV, they can also be seen as an actor in the solar PV niche. One of the PCs identifies this as an opportunity to innovate in a new field, different from its usual core activities (interview 10). The value of induced innovativeness enhances this opportunity. Similarly, another PC aims to integrate a modern electricity infrastructure in a profile building, answering the question, how sustainable can we actually build and live in the future? Solar PV is one fundamental solution, along with other electrical, constructional, and social solutions which are included in this profile project (interview 11). Hence, this regime actor integrates electricity infrastructure development as a core activity and by this provides a future prospect showing how the sectors are all integrated. Again, values are central to this development, and especially synergies from adding it all together connect these values even stronger.

The niche is also affecting the housing regime actors as it provides added values which are viewed as desirable. The $\mathrm{HC}$ in the study evaluates every new construction project to identify whether it is suitable for solar PV (interview 13). In turn, enhanced by the values of sustainability, fair cost, and induced innovativeness, the housing regime actor integrates the solar PV niche to its previous core activities and is thus shaped by the niche development.

In summary, the expanding solar PV niche affects actors from several regimes. Added values enhance interests from both types of regime actors and new opportunities are being shaped in their respective organizations.

\section{Niche empowerment}

The actors in this study are empowering the niche by providing a niche narrative based on their experiences of added values, i.e., they are niche advocates. As presented in the theoretical framework, niche-regime interaction can have different modes and empowerment can be either in a "fit and conform" mode or a "stretch and transform" mode. 
Fair cost relates to producing solar PV electricity for own consumption. This is often exempt from the general tax provision on electricity production which largescale regime producers incur. An increase in decentralized electricity production from solar PV means less tax income for the government. This could imply sales of fewer kWhs from utility companies and lead to financial pressure on these regime actors. Since this development is sanctioned by government via tax exemptions, it can be seen as creating a shift which stretches and transforms the current regime.

The PCs and the RHC have been involved in development projects for solar PV-based electricity systems which have been partly funded by governmental actors (interviews $5,10-11$ ). These actors have actively searched for these funds, inspired by the new possibilities of having their own system. This relates to the value of induced innovativeness and, by granting funds for these projects, governmental actors see that the future electricity infrastructure development includes these large building owners as developers. Thus, induced innovativeness pushes the role of infrastructure developer and can therefore be seen as a "stretch and transform" mode of empowerment.

The design or improvement of a property which includes solar PV can be challenging since it limits the possibility of connecting several buildings under one common contract with the electricity utility. To work around this, one of the PCs designed a new project with several connecting buildings so that all the buildings can be viewed as one (interview 11). At the same time as this action adapts to the current regulatory regime, it puts pressure on it by showing new opportunities on how to connect buildings with solar PV plants. The new project provides new knowledge of how buildings and the electricity system can be integrated for solar PV electricity production. This can challenge the existing legislation to transform and allow new configurations.

The SCs in the study show that it is possible to extend solar PV ownership to people who do not have available space for installation. This also creates the opportunity to utilize available roofs or facades and increase the number of installations. Since these added opportunities for the niche are limited at present by the view that these actors are regular utilities, the SCs try to "fit and conform" with the current regime. This is related to the value of fair cost. Viewing the rules as unfair and debating for changes in the regulations, these SCs put pressure on policymakers to provide equal opportunities for all to benefit from investment in their own solar PV production infrastructure.

Table 4 summarizes the main conclusions from the expanding niche and niche-regime interaction.

\section{Discussion}

The results presented above show how solar PV added a variety of values to owners of large buildings. The identified values are in some aspects similar to previous findings, while other values have not been mentioned in previous studies.

As Sommerfeldt and Muyingo [23] showed, installed solar PV improved the owners' experiences of added values, especially the long-term sustainability of the organizations and a greater sense of belonging together, which overcame the failure of providing a profitable

Table 4 Effects on the expanding niche from added value

\begin{tabular}{|c|c|c|}
\hline Niche-regime interaction & Added values & Effects from added values \\
\hline $\begin{array}{l}\text { Role development through } \\
\text { value creation }\end{array}$ & $\begin{array}{l}\text { Sustainability, fair cost, active engagement, } \\
\text { and increased knowledge of the energy system }\end{array}$ & $\begin{array}{l}\text { - Positive experience of becoming an electricity producer. } \\
\text { - Added values encourage owners to take on the role as } \\
\text { infrastructure developers in a decentralized electricity system. }\end{array}$ \\
\hline $\begin{array}{l}\text { Social network development } \\
\text { in the expanding niche }\end{array}$ & Sustainability, positive atmosphere, and fair cost & $\begin{array}{l}\text { - Decentralized ownership of solar PV increases sustainability } \\
\text { in all three dimensions: environmental, social, and financial. } \\
\text { - The shaping of a social identity among the group of niche } \\
\text { advocates. }\end{array}$ \\
\hline Inclusions of regime actors & $\begin{array}{l}\text { Induced innovativeness, fair cost, sustainability, } \\
\text { increased knowledge of the energy system, } \\
\text { and active engagement }\end{array}$ & $\begin{array}{l}\text { - The importance of how solar PV values relate to values from } \\
\text { other regime actors, i.e., the property companies and housing } \\
\text { companies, in the development of the niche specific social } \\
\text { network. } \\
\text { - Values from solar PV affect regime actor and shape new } \\
\text { organizational values. } \\
\text { - Added values create new opportunities for utilities. } \\
\text { - Added values can shape the reformation of utilities } \\
\text { to become niche advocates for decentralized ownership } \\
\text { of solar PV. }\end{array}$ \\
\hline Niche empowerment & $\begin{array}{l}\text { Induced innovativeness, fair cost, and } \\
\text { increased knowledge of the energy system }\end{array}$ & $\begin{array}{l}\text { - Decentralized ownership of solar PV mostly stretches } \\
\text { current regulatory regimes. } \\
\text { - This is sanctioned by the Swedish government and } \\
\text { displays a shifted mindset. }\end{array}$ \\
\hline
\end{tabular}


investment in their three studied cases. Our study confirms that the added values from solar PV installations go beyond economic profitability and enhance the experience of a successful installation.

Installations of solar PV are often motivated by environmental and economic rationales (e.g., [4, 39]). The findings confirm this and further discuss the practical meaning of these rationales and the added values. Values of sustainability and fair cost relate to the environment and economics, but contain several further dimensions such as identity, fairness, and independence, which are drawn from the concept of values. Here, the connection between value and the concept of values is displayed and influences institutional development in the niche.

Klein and Coffey [21] highlight increased civic engagement as a benefit related to community energy projects. This is similar to the value of active engagement which is found in this study.

They also describe it as challenging to spread information outside the community and that community members are generally not interested in transferring their knowledge to others [21]. The findings in this article indicate the opposite; owners of large buildings are very willing to communicate externally about their solar PV plants. This might be explained by the fact that different actor groups are in focus, owners of large buildings in this article which have a more mainstream character, while Klein and Coffey [21] look at radical grassroot communities. The finding is, however, important to be able to understand the growth of the niche technology, and, not least, the characters of the actors who facilitate this growth. While the radical grassroot communities can provide important organizational innovations and institutional set-ups as shown in Klein and Coffey [21], the mainstream owners interviewed in this article show a desire to extend the niche beyond their own organizations and are willing to engage in this task.

The results also show that solar PV on large buildings adds values which are important for the creation of a stronger social network and, thereby, contribute to expanding the niche. This finding is in line with van der Schoor and Scholtens [22] who state that a decentralized ownership structure in the energy system could lead to better social coherence, which is fundamental for the creation of strong social networks. Shared values are important for the inclusion in a social group [25], and although the social network around the niche is heterogeneous, the added values from solar PV deployments become common denominators for the desire to enter into this group.

In addition, active engagement is crucial for the social acceptance and success of community energy projects $[13,21,22]$. With increased responsibilities for the owners of solar PV, active engagement from users and producers is not only an additional value, but is a necessary step toward a decentralized energy system. Interestingly, the utilities in this study say that more work is needed to give increased and closer customer relations; however, the experienced gains are significant and affect the rest of the business in a positive way. Thus, relating to the niche-regime interplay outlined in the theory, certain values could bridge between the niche and the regime.

To actively undertake both the role of electricity producer and that of infrastructure developer relates to the discussion on the new electricity producers' ability to take action in the decentralized energy system as presented by Büscher and Sumpf [5]. The results in this article show that the added values increase the actors' desire to pursue the roles actively, since they are directly linked to their own benefit. As Wittmayer et al. [13] point out, these role developments are linked with the success of the transition, and values become central in the actors' desire to undertake the necessary roles.

The analysis of experienced added values which shape and shift the mindset among actors owning their own solar PV plants has relevance for understanding the role of values in ongoing transitions. A change of cognitive routines is a well-established dimension in the sustainability transitions research field [12,30], and the results from this study substantiate this cognitive change in the context of decentralized ownership of solar PV. In addition, the results also provide a better understanding of the role development and the increase of organizational engagement in solar PV deployment. This is in line with recent rule updates in the EU [6] and can contribute to the understanding of how to stimulate active energy citizens and the development of decentralized energy systems.

\section{Conclusions}

The purpose of this article was to investigate what added values solar PV on large buildings in Sweden gives to their owners and how this affects the transformation of the electricity system. Two research questions were formulated: (i) what added values do actors with large buildings associate with their solar PV plants and (ii) how do these values contribute to the ongoing expansion of the solar PV niche in Sweden?

The results of this study show that the studied actors experience the creation of a broad set of values, namely sustainability, fair cost, active engagement, knowledge development, induced innovativeness, and positive atmosphere. These added values contribute to the formation of new roles, shaping group identity in the social network of the niche and substantiating positive niche narratives. 
The added values are part of the process where owners of large buildings overcome challenges linked with installing solar PV, learning and undertaking new roles as electricity producers and electricity infrastructure developers. Producing electricity becomes a positive experience through the added values, despite added responsibilities. The value of induced innovativeness is central in the desire to develop the local electricity infrastructure further. By innovating and creating new solutions for the actors' own buildings, they become infrastructure developers of the new decentralized electricity infrastructure. From this, it can be concluded that added values affect actors' desire to undertake new roles in the decentralized electricity system.

Added values help shape the social identity within the social network of niche actors. This identity is important as it strengthens the network. In addition, actors from different regimes adapt to this social identity when entering the niche. Therefore, the conclusion is that values play an important role for the development of the social network in the expanding niche.

Added values shape the positive niche narrative and create motivation and engagement among actors when utilized for niche advocacy. Thus, this study shows that rule structures of the expanding niche are affected by added values and can direct a shifted narrative among actors. By performing a detailed analysis, important information can be extracted regarding the future path for decentralized ownership of solar PV in Sweden. We therefore conclude that added values shape the positive niche narrative among niche advocates and give direction for policy development related with the niche.

Given the overall relationship between values and the effects on niche development that can be drawn from this study, we want to emphasis that values are indeed relevant for the study of sustainability transitions. The observation that values shape the initial process, develop through the implementation and finally define the niche technology after its finalization, provides insights on how values affect the developing niche. The conclusion, therefore, is that focusing on values in sustainability transition analysis can increase the understanding of informal institutional development and, hence, the fundaments by which a niche technology is developed and eventually shapes its sociotechnical system.

The selection of interviewees in the study who represent different organizations is a good representation of actors linked to large buildings in Sweden. However, as a representation of the greater movement of decentralized ownership of solar PV, it is limited. Thus, further research with a wider selection of decentralized owners of solar PV would be needed to better understand the diverse set of actors engaging in this niche. The research questions can also open up for the study of certain effects, such as how values provide a more active energy citizen and how shared values influence collective actions in the community. Furthermore, a specific actor could be studied in depth since the motivations and institutions of actors in this article differ from one another. Also, a focus on the regime actor and how added values from solar PV affect attitudes and development of this actor could provide better understanding of the regime dynamics in relation to the expanding niche. Moreover, to increase understanding of values in the shaping of rule structures for expanding niches and the niche regime interplay, studies of additional niches are needed.

\section{Supplementary information}

Supplementary information accompanies this paper at https://doi.org/10. 1186/s13705-020-0239-7.

Additional file 1. Interview guide

\section{Abbreviations}

CF: Cooperative farm; CHA: Cooperate housing association; HC: Housing company; MLP: Multi-level perspective; PC: Property company;

PV: Photovoltaic; RHC: Rental housing cooperative; SC: Share cooperative; VC: Village community

\section{Acknowledgements}

The authors would like to thank the region of Västra Götaland for funding the project. We are also grateful to Anna Bergek, Ewa Wäckelgård, and participants in the REESBE school for industrial PhD for commenting on the manuscripts for the article, as well as the comments from three anonymous reviewers which greatly contributed to its improvement and, finally, a special thanks to all interviewees who contributed with their experiences and expertise from owning or working with solar PV.

Authors' contributions

Both authors have contributed collectively to the research and the development of the article. Both authors read and approved the final article.

\section{Funding}

This research project was funded by the region of Västra Götaland, within the larger project of "Soligt och Smart MN 2016-00143". Open access funding provided by Dalarna University.

\section{Availability of data and materials}

Data can be shared on request. All requests can be sent to the corresponding author.

Ethics approval and consent to participate

All interviewees participated voluntarily in the study. The interviewees and respective organizations were anonymized in the writing of the article. All the interview material was handled and stored securely by the authors.

Consent for publication

Not applicable

Competing interests

The authors declare that they have no competing interests.

\section{Author details}

${ }^{1}$ RISE, Research Institutes of Sweden, Box 857, SE-501 15 Borås, Sweden.

2Dalarna University, SE-791 88 Falun, Sweden. ${ }^{3}$ Mälardalen University, SE-721 23 Västerås, Sweden. ${ }^{4}$ Jönköping International Business School, Box 1026, SE-551 11 Jönköping, Sweden. 
Received: 31 January 2019 Accepted: 9 January 2020

Published online: 04 February 2020

\section{References}

1. IEA/REN21 (2017) Renewables 2017 global status report, REN21 Secretariat Paris

2. Lindahl J (2018) National survey report of PV power applications in sweden 2017. International Energy Agency Co-Operative Programme on Photovoltaic PowerSystems

3. Energimyndigheten (2016) Förslag till ökad användning av solel, Statens Energimyndighet, Eskilstuna

4. Raven R, Kern F, Verhees B, Smith A (2016) Niche construction and empowerment through socio-political work. A meta-analysis of six lowcarbon technology cases. Environ Innov Soc Transitions 18:164-180

5. Büscher C, Sumpf P (2015) "Trust" and "confidence" as socio-technical problems in the transformation of energy systems. Energy, sustainability and Society. 5:34

6. Commission $E_{1}$ (2016) Proposal for a directive of the european parliament and of the council on the Promotion of the Use of Energy from Renewable Sources (recast) COM/2016/0767 Final/2-2016/0382 (COD). European Comission Belgium.

7. SOU (2018) Mindre aktörer i energilandskapet - Förslag med effekt, Norstedts Juridik, Stockholm, p 76

8. SFS (2014) Lag om ändring i inkomstskattelagen (1999:1229), p 1468

9. Sernhed K, Gåverud H (2014) Koncessionsplikten-i kollision med utbyggd mikroproduktion, Elforsk, Stockholm

10. Geels FW (2002) Technological transitions as evolutionary reconfiguration processes: a multi-level perspective and a case-study. Res Policy 31:12571274

11. Smith A, Raven R (2012) What is protective space? Reconsidering niches in transitions to sustainability. Res Policy 41:1025-1036

12. Geels FW, Schot J (2007) Typology of sociotechnical transition pathways. Res Policy 36:399-417

13. Wittmayer JM, Avelino F, van Steenbergen F, Loorbach D (2017) Actor roles in transition: insights from sociological perspectives. Environ Innov Soc Transitions. 24:45-56

14. Palm A (2016) Local factors driving the diffusion of solar photovoltaics in Sweden: a case study of five municipalities in an early market. Energy Res Soc Sci 14:1-12

15. Huijben JC, Verbong GP (2013) Breakthrough without subsidies? PV business model experiments in the Netherlands. Energy Policy 56:362-370

16. Hamwi M, Lizarralde I (2017) A review of business models towards serviceoriented electricity systems. Procedia CIRP 64:109-114

17. Phimister E, Roberts D (2012) The role of ownership in determining the rural economic benefits of on-shore wind farms. J Agric Econ 63:331-360

18. Hain J, Ault G, Galloway S, Cruden A, McDonald J (2005) Additional renewable energy growth through small-scale community orientated energy policies. Energy Policy 33:1199-1212

19. Walker G, Devine-Wright $P$ (2008) Community renewable energy: what should it mean? Energy Policy 36:497-500

20. Seyfang G, Park JJ, Smith A (2013) A thousand flowers blooming? An examination of community energy in the UK. Energy Policy 61:977-989

21. Klein SJ, Coffey S (2016) Building a sustainable energy future, one community at a time. Renew Sust Energ Rev 60:867-880

22. van der Schoor T, Scholtens B (2015) Power to the people: local community initiatives and the transition to sustainable energy. Renew Sust Energ Rev 43:666-675

23. Sommerfeldt N, Muyingo H (2015) Lessons in Community Owned PV From Swedish Multi-Family Housing Cooperatives. Proceedings of the 31st European Photovoltaic Solar Energy Conference and Exhibition, Hamburg, pp 2745-2750

24. Huber F, Herrmann A, Morgan RE (2001) Gaining competitive advantage through customer value oriented management. J Consum Mark 18:41-53

25. Thome H (2015) Values, sociology of. Int Encyclopedia Soc Behav Sci 25:4753

26. Ledden L, Kalafatis SP, Samouel P (2007) The relationship between personal values and perceived value of education. J Bus Res 60:965-974

27. Markard J, Raven R, Truffer B (2012) Sustainability transitions: an emerging field of research and its prospects. Res Policy 41:955-967
28. Geels FW (2014) Regime resistance against low-carbon transitions: introducing politics and power into the multi-level perspective. Theory Culture Soc 31:21-40

29. Ulmanen JH, Verbong GPJ, Raven RPJM (2009) Biofuel developments in Sweden and the Netherlands: protection and socio-technical change in a long-term perspective. Renew Sust Energ Rev 13:1406-1417

30. Markard J, Suter M, Ingold K (2016) Socio-technical transitions and policy change-advocacy coalitions in Swiss energy policy. Environ Innov Soc Transitions. 18:215-237

31. Markard J (2018), Transition 2.0-New conceptual challenges for sustainability transition studies. Abstracts of the 9th International Sustainability Transitions Conference (IST 2018). Oxford Abstracts: p. 49.

32. Geels FW (2018) Disruption and low-carbon system transformation: progress and new challenges in socio-technical transitions research and the multilevel perspective. Energy Res Soc Sci 37:224-231

33. Boon WP, Moors EH, Meijer AJ (2014) Exploring dynamics and strategies of niche protection. Res Policy 43:792-803

34. Geels FW, Kern F, Fuchs G, Hinderer N, Kungl G, Mylan J et al (2016) The enactment of socio-technical transition pathways: a reformulated typology and a comparative multi-level analysis of the German and UK low-carbon electricity transitions (1990-2014). Res Policy 45:896-913

35. Sutherland L-A, Peter S, Zagata L (2015) Conceptualising multi-regime interactions: the role of the agriculture sector in renewable energy transitions. Res Policy 44:1543-1554

36. Elzen B, Van Mierlo B, Leeuwis C (2012) Anchoring of innovations: assessing Dutch efforts to harvest energy from glasshouses. Environ Innov Soc Transitions 5:1-18

37. Avelino F, Rotmans J (2009) Power in transition: an interdisciplinary framework to study power in relation to structural change. Eur J Soc Theory 12:543-569

38. Huijben JCCM, Verbong GPJ, Podoynitsyna KS (2016) Mainstreaming solar: stretching the regulatory regime through business model innovation. Environ Innov Soc Transitions. 20:1-15

39. Palm J (2018) Household installation of solar panels - motives and barriers in a 10-year perspective. Energy Policy 113:1-8

\section{Publisher's Note}

Springer Nature remains neutral with regard to jurisdictional claims in published maps and institutional affiliations.

Ready to submit your research? Choose BMC and benefit from:

- fast, convenient online submission

- thorough peer review by experienced researchers in your field

- rapid publication on acceptance

- support for research data, including large and complex data types

- gold Open Access which fosters wider collaboration and increased citations

- maximum visibility for your research: over $100 \mathrm{M}$ website views per year

At $\mathrm{BMC}$, research is always in progress.

Learn more biomedcentral.com/submissions 